obstructed nuclear inspectors. Other suggestions included a moratorium on uranium enrichment, or allowing it only at plants under international control.

South Korea argued that withdrawal from the treaty should become contingent on approval by the United Nations Security Council, a rule that would have prevented North Korea from pulling out. And a host of countries, including Brazil and Egypt, called for substantial reductions in the nuclear arsenals of the five weapons states.

But each proposal raises its own issues among the other delegates. The United States is likely to resist any effort to curtail its nuclear arsenal. And placing restrictions on nuclear technology in certain states will meet resistance from members such as France and Germany, which profit from sales abroad.

The situation is so difficult that most observers doubt much will come of the conference. The treaty is unlikely to be amended for fear that the entire document may fall apart, says Michael Levi of the Brookings Institution, a non-partisan think-tank in Washington.

A more likely outcome could be a 'consensus document' on how to reinterpret the treaty. Such documents, which require the unanimous approval of all member states, have been created twice before: once in 1995 and again in 2000, in which a 13-step plan towards disarmament was proposed. A new one to strengthen the role of inspectors might stand a chance of success. Still, as Levi points out, "Iran would have to agree to it", which is unlikely. Other members might try to argue that the inspections of weapons states, which are currently voluntary, should be strengthened as well, but the 'big five' would be unlikely to approve.

Johnson is still hopeful that agreement will be reached, but says it won't be easy given the acrimonious tone of the conference. She calls on nations to make compromises - or risk nuclear weapons technology spreading out of control. "Quite a lot of states are protecting their own interests over and above international security," she fears.
IMAGE

UNAVAILABLE FOR COPYRIGHT REASONS
IMAGE

UNAVAILABLE FOR COPYRIGHT REASONS

\title{
Polio fight falters as Yemen and Java report fresh cases
}

\section{Carina Dennis, Sydney}

Polio is spreading to countries previously considered free of the disease, following a vaccine boycott in Nigeria in 2003. An outbreak in Yemen has sparked fears of an epidemic in the poorly immunized Middle Eastern nation. And the virus has now reached southeast Asia, with four cases confirmed in Indonesia last week.

Polio has not been seen in Yemen and Indonesia for a decade. Genetic analysis shows that the virus appearing in both areas is similar to the one that caused a 2003 outbreak in Nigeria. Polio vaccines were rejected in northern Nigerian states after Muslim clerics claimed they had been contaminated with HIV and contraceptives. Sixteen 'polio-free' countries have reported cases since 2003.

"The recent outbreaks can be traced back to that boycott," says Arun Thapa, an adviser on polio eradication in southeast Asia for the World Health Organization (WHO), based in New Delhi.

In April, the WHO confirmed 22 cases in Yemen, and health officials anticipate further infections because of low immunization rates among the nation's children. "We expect there will be many times this number," says Mohamed Wahdan, the WHO's Eastern Mediterranean polio adviser.

Middle Eastern nations have been on high alert for polio since December 2004 and many have already started preventative vaccination programmes. "Unfortunately, the virus spread ahead of the campaign in Yemen," says Wahdan. "We hope to be ahead of the virus in other regions."

This month, Yemen will initiate a houseto-house campaign to vaccinate all its 3 million children under 5 years of age. Health officials are using a polio vaccine specifically targeted at the virus responsible for the outbreak, which they say provides greater immunity with fewer doses. "We believe it is the best tool in the face of an epidemic," says Wahdan.

In Indonesia, health officials are confident the virus can be restricted to the small villages in West Java where the four cases were reported. "The immunization level in Indonesia has been good, with 95\% coverage of children," says Bardan Rana, the WHO's immunization officer in the country. But officials are taking no chances and are giving supplementary immunization to 5.2 million children under the age of five in West Java and surrounding provinces.

Although the recent outbreaks do not bode well for the eradication of polio, Thapa says he is more concerned about the situation in India. "It is the largest polio-endemic country and has been a source of wild poliovirus for other countries in the past."

Officials suspect the virus travelled to southeast Asia through Saudi Arabia, a popular destination for Indonesian workers and Muslim pilgrims. "As long as there is polio is in the world and a lot of travel, we expect the virus to be imported," says Rana. 